\title{
MENINGKATKAN EFISIENSI DAN PROFITABILITAS PADA USAHA TANI BAWANG MERAH DI KABUPATEN BREBES
}

\author{
Imron Rosyadi, Nur Achmad, dan Triyono \\ Fakultas Ekonomi \\ Universitas Muhammadiyah Surakarta \\ E-mail: imronkaprawi@yahoo.co.id
}

\begin{abstract}
Onion Agriculture has benefited farmers, but the benefits are very small as compared with production costs that have been published. This is consistent with the results of research Rosyadi (2009) which states that the level of profit is not sufficient to meet the needs of peasant household economy. Or in other words, onion farm in the location of the study did not provide significant benefits for the economy of peasant households. To solve the problems encountered, partner activities and implementation team agreed that this method is appropriate is the format of training and consultancy services "Implementation of Working Capital Management At the Onion Farm." Indicators of success of this activity can be seen from some important things that are revealed through in-depth interview participants. Based on in-depth interview is known that onion farmers to understand the importance of working capital management and practice how to manage working capital well, efficiently and effectively. IbM event has implications for government policy for the district soon realized: (a) the availability of new varieties that productive, adaptive and resistant to pests or diseases, (b) availability of production technology and management of quality seeds, the concept of quality assurance and standardization as the first step to build a national seed industry a strong and independent, (c) Availability of environmentally friendly agricultural technologies and efficient by utilizing local resources in an optimal and sustained to produce horticultural products are the opportunities and open to the emergence of a modern and efficient industrial facilities in various regions, (d) The availability of pest or disease control technology based on the use of natural enemies and reducing synthetic pesticides as low as possible, (e) The availability of postharvest technology for efficient packaging, conservation of fresh quality, product diversification is associated with increased value-added horticultural industry. So the activity is generally considered a success based on in-depth interviews that reveal some things about: (i) working capital management with a good, efficient and effective, (ii) pass the cost efficiency of production, (iii) allocating cash and stock in order to maintain the sustainability of agricultural onion, (iv) understand and can do proper financial planning and benefits of capital budgeting and (v) increase the working capital of onion farming.
\end{abstract}

Kata kunci: pengelolaan modal kerja, efisiensi, profitabilitas 


\section{PENDAHULUAN}

\section{Analisis Situasi}

Kabupaten Brebes merupakan salah satu kabupaten di Provinsi Jawa Tengah, Indonesia. Luas wilayahnya 1.657,73 km², jumlah penduduknya sekitar 1.767 .000 jiwa (2003). Ibukotanya adalah Brebes. Brebes merupakan kabupaten dengan jumlah penduduk paling banyak di Jawa Tengah. Kabupaten Brebes terletak di bagian barat Provinsi Jawa Tengah, dan berbatasan langsung dengan wilayah Provinsi Jawa Barat. Ibukota kabupaten Brebes terletak di bagian timur laut wilayah kabupaten. Kota Brebes bersebelahan dengan Kota Tegal, sehingga kedua kota ini 'menyatu'.

Ibukota kabupaten Brebes terletak sekitar 177 km sebelah barat Kota Semarang, atau $330 \mathrm{~km}$ sebelah timur Jakarta. Kabupaten ini dilalui jalur pantura, dan menjadi pintu masuk utama Jawa Tengah di sisi barat dari arah Jakarta/Cirebon, sehingga Brebes memiliki posisi yang cukup strategis. Selain itu, juga terdapat jalan provinsi sebagai jalur alternatif menuju ke kota-kota di Jawa Tengah bagian selatan seperti Purwokerto, Kebumen, dan Yogyakarta. Brebes merupakan kabupaten yang cukup luas di Provinsi Jawa Tengah. Sebagian besar wilayahnya adalah dataran rendah. Bagian barat daya merupakan dataran tinggi dengan puncaknya Gunung Pojoktiga dan Gunung Kumbang; sedang bagian tenggara terdapat pegunungan yang merupakan bagian dari Gunung Slamet. Dengan iklim tropis, curah hujan rata-rata 18,94 mm per bulan. Kondisi itu menjadikan kawasan tersebut sangat potensial untuk pengembangan produk pertanian, khususnya bawang merah. Demikian juga dengan Siwuluh yang merupakan salah satu Desa di Kecamatan Bulakamba Kabupaten Brebes (lihat gambar peta lokasi mitra). Desa Siswuluh merupakan salah satu desa sentra penghasil bawang merah di Kabupaten Brebes.

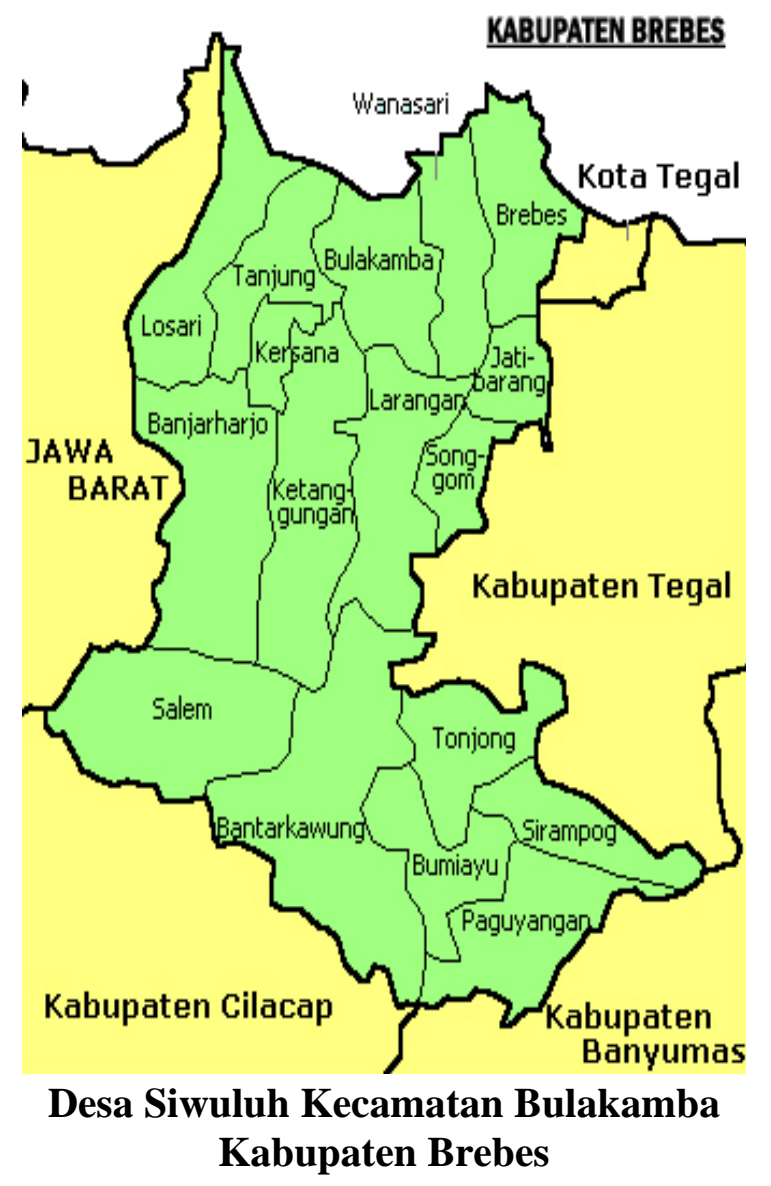

Gambar 1. Peta Lokasi Mitra

Keterangan Gambar: tanda (f\&) merupakan lokasi kelompok usahatani bawang merah di Desa Siwuluh Bulakamba Kabupaten Brebes

Bawang Merah bagi Kabupaten Brebes merupakan trademark mengingat posisinya sebagai penghasil terbesar komoditi tersebut di tataran nasional serta memilki brand image yang baik bagi konsumen bawang merah di Indonesia. Bawang merah Brebes terkenal dengan kualitas yang lebik dari bawang merah yang berasal dari daerah lain di Indonesia atau luar negeri seperti, Thailand dan China. Bawang merah asli Brebes memiliki cita rasa tinggi, yaitu lebih menyengat dan harum serta produk jadi (bawang 'goreng')-nya lebih enak dan 'gurih'. Bawang merah merupakan salah satu produk andalan dan unggulan 
sektor industri Kabupaten Brebes. Hal ini ditegaskan dalam Peraturan Daerah Kabupaten Brebes Nomor 8 tahun 1986 bahwa lambang daerah dalam bentuk bulat telur serta gambar bawang merah melambangkan bahwa telur asin dan bawang merah merupakan hasil spesifik daerah Brebes (Pemkab Brebes, 2008)

Produksi bawang merah di Kabupaten Brebes dari tahun ke tahun mengalami peningkatan. Pada tahun 2007 sebesar 159.342, 6 ton, awal tahun 2008 meningkat menjadi 179.227, 8 ton (Bappeda Brebes, 2008). Sementara harga bawang merah cenderung berfluktuatif, pada awal 2007 harga bawang merah sebesar 7.000/kg, pada awal tahun 2008 turun menjadi 6.000/ kg, pada pertengahan tahun 2008 naik kembali menjadi 10.000/kg (BPS Brebes, 2008). Fluktuasi harga bawang merah menjadi salah satu penyebab berkurangnya keuntungan petani bawang merah di Kabupaten Brebes. Fluktuasi harga bawang merah disebabkan terjadinya over supply akibat panen raya atau masuknya bawang merah impor (Agustian et al., 2005). Penyebab yang lain secara berurutan adalah fluktuasi harga pupuk, fluktuasi harga obatobatan, fluktuasi harga bibit, produksi turun akibat iklim dan produksi turun karena HPT (Nurasa dan Darwis, 2007; Agustian et al., 2005; Saptana, et al., 2006).

Keberadaan kelompok usahatani bawang merah di desa Siwuluh sangat dirasakan kontribusinya bagi petani bawang merah dalam meningkatkan kesejahteraannya. Kelompok usahatani bawang berperan memberikan informasi dan penjelasan kepada pemerintah Desa, Kecamatan maupun Kabupaten tentang berbagai persoalan yang dihadapi oleh petani bawang merah, seperti harga bawang merah yang cenderung fluktuasi sehingga merugikan konsumen; kelangkaan pupuk di pasaran, sehingga harga pupuk menjadi mahal; serta persoalan masuknya bawang merah impor di pasar bawang Brebes. Koordinasi para petani bawang merah yang dilakukan kelompok usahatani bawang merah sedikit-banyak memberikan solusi atas berbagai persoalan yang dihadapi petani serta mampu meningkatkan posisi tawar (bargaining power) terhadap para tengkulak (bakul bawang) bawang merah yang seringkali merugikan petani.

Hasil analisis usahatani bawang merah di Kabupaten Brebes oleh Nurasa dan Darwis (2007) menunjukan bahwa produksi yang dihasilkan dari usahatani bawang merah cukup tinggi yaitu mencapai 11,1 ton/ha dalam satu tahun dengan nilai yang diperoleh sebesar Rp 70.892.000. Sementara keutungan yang diperoleh dalam satu tahun atau dua kali tanam hanya sebesar Rp. 6.831.000, dengan $\mathrm{R} / \mathrm{C}$ rasio sebesar 1,1. Selanjutnya Nurasa dan Darwis (2007) memberikan kesimpulan bahwa berusahatani bawang merah telah dapat memberikan keuntungan, akan tetapi menurut para petani tingkat keuntungan yang diperoleh belum cukup untuk dapat memenuhi kebutuhan ekonomi rumah tangga petani.

Penelitian yang dilakukan oleh Rosyadi (2009) tentang efisiensi dan profitabilitas usahatani bawang merah di Kabupaten Brebes dengan mengambil 6 (enam) desa di Kecamatan Bulakamba sebagai lokasi penelitian, melaporkan bahwa rata-rata skor efisiensi usahatani ke enam desa tersebut sebesar 64,84\%. Berdasarkan skor rata-rata efisiensi tersebut Rosyadi (2009) menyimpulkan bahwa usahatani yang dilakukan oleh petani di lokasi penelitian tidak efisien, karena skor efisiensinya kurang dari 100 persen. Sementara untuk hasil analisis profitabilitas menunjukan bahwa produksi bawah merah ha-1 dalam dua kali tanam dalam setahun cukup besar yaitu 11,13564 ton $(11.135,64 \mathrm{~kg})$ dengan nilai 
penerimaan (revenue) produksi sebesar Rp.69.976.500. Sedangkan keuntungan bersih setelah dikurangi berbagai pengeluaran (biaya produksi) sebesar Rp.4.670.114, dengan R/C rasio sebesar 1,1.

Berdasarkan hasil analisis ini Rosyadi (2009) menyimpulkan bahwa berusahatani bawang merah telah dapat memberikan keuntungan bagi petani, namun keutungan yang diperoleh terhitung sangat kecil jika dibandingkan dengan biaya produksi yang telah dikeluarkan. Hal ini sesuai dengan hasil pengamatan (interview in depth) peneliti dilapangan terhadap petani yang menyatakan bahwa tingkat keuntungan yang diperoleh belum cukup untuk dapat memenuhi kebutuhan ekonomi rumah tangga petani. Atau dengan dengan kalimat lain, usahatani bawang merah dilokasi penelitian tidak memberikan keuntungan yang siginfikan (unprofitable) terhadap ekonomi rumah tangga petani.

\section{Rumusan Masalah}

Perolehan keuntungan yang kecil oleh petani disebabkan tingginya biaya produksi (output) yaitu 90\% dari total pendapatan serta disebabkan oleh fluktuasi harga output sebesar 33,33\%, fluktuasi harga pupuk sebesar 28,57\%, flutuasi harga obatobatan 55,56\%, fluktuasi harga bibit, iklim dan hama pasca tanam (Nurasa dan Darwis, 2007; Agustian et al., 2005; Saptana, et al., 2006; Rosyadi, 2009). Sehingga dapat dirumuskan permasalahan sebagai berikut: (1) Apakah pengusahatani bawang merah sudah mengelola modal kerja (kas, kredit untuk rakyat/KUR, persediaan) secara efisien, efektif dan tepat; (2) Apakah pengusahatani bawang merah sudah melaukan efisiensi pada input (biaya) produksi? (3) Apakah sebagian besar keuntungan dari usahatani bawang merah digunakan untuk meningkatkan modal kerja? (4) Apakah pengusahatani bawah merah sudah mengalokasikan kas dan persediaan (bibit bawang merah) yang harus dipertahankan untuk menjaga kontinuitas usahatani? Dan (5) Apakah pengusahatani bawang merah sudah melakukan perencanaan (anggaran) modal dan keuntungan secara tepat?

\section{Tujuan dan Kontribusi Kegiatan}

Pengelolaan modal kerja usahatani secara benar merupakan hal penting yang harus dilakukan oleh pengusahatani bawang merah agar dapat meningkatkan laba dan efisiensi biaya produksi, sehingga dapat menjamin keberlangsungan usaha yang pada gilirannya dapat meningkatkan kesejahteraan petani bawang merah. Kegiatan ini dirancang sedemikian rupa, sehingga memungkinkan pengusahatani dapat meningkatkan pemahaman dan praktek-praktek sederhana bagaimana mengelola modal kerja yang efisien dan mengidentifikasi laba-rugi usaha. Secara lebih detail tujuan kegiatan ini adalah: (1) Pengusahatani bawang merah mampu mengelola modal kerja (kas, kredit untuk rakyat/KUR, persediaan bibit dst.); (2) Pengusahatani bawang merah mampu melakukan efisiensi terhadap input (biaya produksi) sehingga biaya produksi dapat diminimalisasi; (3) Pengusahatani bawang merah mampu meningkatkan besarnya modal kerja melalui sebagaian keuntungan usaha yang diperoleh; (4) Pengusahatani bawang merah mampu mengalokasikan kas dan persediaan (bibit bawang merah) yang harus dipertahankan untuk menjaga kontinuitas usahatani; dan (5) Pengusahatani bawang merah dapat melakukan perencanaan (anggaran) modal dan prediksi keuntungan secara tepat.

Kegiatan IbM ini, baik secara konseptual maupun riil memberikan beberapa kontribusi atau implikasi perubahan kepada petani bawang merah yaitu: (1) Penggunaan modal kerja usahatani 
yang terdiri dari kas, kredit dan persediaan bibit menjadi lebih tekontrol dan efisien; (2) Biaya produksi (input) menjadi lebih kecil (menurun), karena ada upaya efisiensi yang dilakukan oleh petani; (3) Modal kerja menjadi meningkat secara signifikan, karena secara proporsional sebagian keuntungan dialokasikan untuk meningkatkan modal kerja; (4) Keberlangsungan usaha menjadi semakin pasti (establish), karena ada pengalokasian kas dan persediaan untuk menjamin kontinuitas usahatani dan (5) Modal kerja dan keuntungan menjadi sangat terkontrol, karena petani mampu merencanakan keuangan secara lebih tepat dan pasti.

\section{Tinjauan Pustaka}

Manajemen modal kerja, menurut Burton A. Kolb adalah: "Working capital management encompasses the administration and control of current assets, utilization of short-term financing via various current liability sources, and control of the amount of net working capital". Sedangkan Weston dan Brigham (2006) mengemukakan: "Manajemen modal kerja mengacu pada semua aspek penatalaksanaan aktiva lancar dan utang lancar.”

Dua definisi di atas menunjukkan bahwa manajemen modal kerja adalah kegiatan yang mencakup semua fungsi manajemen atas aktiva lancar dan kewajiban jangka pendek perusahaan. Adapun sasaran yang ingin dicapai dari manajemen modal kerja adalah: (i) memaksimalkan nilai perusahaan dengan mengelola aktiva lan car sehingga tingkat pengembalian investasi marjinal adalah sama atau lebih besar dari biaya modal yang digunakan untuk membiayai aktiva-aktiva tersebut; (ii) meminimalkan dalam jangka panjang-biaya modal yang digunakan untuk membiayai aktiva lancar dan (iii) pengawasan terhadap arus dana dalam aktiva lancar dan ketersediaan dana dari sumber utang, sehingga perusahaan selalu dapat me-menuhi kewajiban keuangannya ketika jatuh tempo.

Dari ketiga sasaran di atas, sasaran ketiga mengindikasikan bahwa perusahaan harus mempertahankan likuiditas yang cukup. Modal kerja yang harus tersedia dalam perusahaan harus cukup jumlahnya dalam arti harus mampu membiayai pengeluaran-pengeluaran atau operasi perusahaan sehari-hari. Modal kerja yang cukup akan memberikan keuntungan bagi perusahaan, antara lain: (i) melindungi perusahaan terhadap krisis modal kerja karena turunnya nilai dari aktiva lancar; (ii) memungkinkan perusahaan untuk dapat membayar semua kewajiban-kewajiban tepat pada waktunya; (iii) menjamin dimilikinya kredit standing perusahaan semakin besar dan memungkinkan bagi perusahaan untuk dapat menghadapi ke-sulitan keuangan yang mungkin terjadi; (iv) memungkinkan perusahaan umuk memiliki persediaan dalam jumlah yang cukup untuk melayani para konsumennya; (v) memungkinkan perusahaan untuk memberikan syarat kredit yang lebih menguntungkan kepada para langganannya dan (vi) memungkinkan bagi perusahaan untuk dapat beroperasi dengan lebih efisien karena tidak ada kesulitan umuk memperoleh barang atau jasa yang dibutuhkan.

Penentuan jumlah modal kerja yang dianggap cukup bagi suatu perusahaan dipengaruhi beberapa faktor, yaitu: (i) Sifat atau tipe perusahaan. Modal kerja dari suatu perusahaan jasa relatif akan lebih rendah daripada kebutuhan modal kerja perusahaan industri. Perusahaan jasa biasanya memiliki atau harus menginvestasikan modal -modalnya sebagian besar pada aktiva tetap yang digunakan untuk memberikan pelayanan atau jasanya kepada masyarakat. Sebaliknya perusahaan industri harus mengadakan investasi yang cukup besar dalam aktiva lancar agar perusahaannya tidak 
mengalami kesulitan dalam operasinya sehari-hari. Perusahaan yang memproduksi barang memburuhkan modal kerja relatif besar daripada perusahaan dagang; (ii) Waktu yang dibutuhkan untuk memproduksi atau memperoleh barang yang akan dijual serta harga per-satuan dari barang tersebut. Makin panjang waktu yang dibutuhkan untuk memproduksi barang atau untuk memperoleh barang tersebut, maka akan makin besar pula modal kerja yang dibutuhkan. Selain itu, harga pokok persatuan barang yang semakin besar juga akan membutuhkan modal kerja makin besar pula; (iii) Syarat pembelian bahan atau barang dagangan. Jika syarat kredit yang diterima pada waktu pembelian menguntungkan, semakin sedikit uang kas yang harus disediakan untuk diinvestasikan dalam persediaan bahan ataupun barang da-gangan; (iv) Syarat penjualan. Semakin lunak kredit yang diberikan oleh perusahaan kepada para pembeli akan mengakibatkan semakin besarnya jumlah modal kerja yang harus diinvestasikan dalam piutang dan (v) Tingkat perputaran persediaan. Semakin tinggi tingkat perputaran persediaan maka jumlah modal kerja yang dibutuhkan semakin rendah.

Hasil analisis keunggulan komparatif dan kompetitif bebera komoditas pertaninan, yang dilakukan oleh P3SEP (2005) menunjukan bahwa komoditas bawang merah, baik di Brebes (Jawa Tengah) maupun di Simalungun (Sumatera Utara) memlliki keungguian komparatif yang tinggi, masing-masing dengan nilai koefisien DRCR 0,49--0,51, dan juga memiliki keunggulan kompetitif dengan nilai koefisien PCR 0,40-0,50. Cabe merah mem-berikan gambaran yang sama. Usa-hatani cabe merah di Brebes, dan di Simalungun memiliki keunggulan komparatif yang sangat tinggi, masing-masing dengan nilai koefisien DRCR 0,28-0,31 dan memiliki keunggulan kompetitif yang juga tinggi dengan nilai koefisien PCR 0,31-0,47.-

Hasil analisis usahatani bawang merah di Kabupaten Brebes oleh Nurasa dan Darwis (2007) menunjukan bahwa produksi yang dihasilkan dari usahatani bawang merah cukup tinggi yaitu mencapai 11,1 ton/ha dalam satu tahun dengan nilai yang diperoleh sebesar Rp 70.892.000. Sementara keutungan yang diperoleh dalam satu tahun atau dua kali tanam hanya sebesar Rp. 6.831.000, dengan $\mathrm{R} / \mathrm{C}$ rasio sebesar 1,1 . Selanjutnya Nurasa dan Darwis (2007) memberikan kesimpulan bahwa berusahatani bawang merah telah dapat memberikan keuntungan, akan tetapi menurut para petani tingkat keuntungan yang diperoleh belum cukup untuk dapat memenuhi kebutuhan ekonomi rumah tangga petani.

Perolehan keuntungan yang kecil oleh petani disebabkan tingginya biaya produksi (output) yaitu $90 \%$ dari total pendapatan serta disebabkan oleh fluktuasi harga output sebesar 33,33\%, fluktuasi harga pupuk sebesar $28,57 \%$, flutuasi harga obatobatan 55,56\%, fluktuasi harga bibit, iklim dan hama pasca tanam (Nurasa dan Darwis, 2007; Agustian et al., 2005; Saptana, et al., 2006). Sehingga dapat dirumuskan permasalahan sebagai berikut:

Lebih lanjut Nurasa dan Darwis (2007) menjelaskan bahwa dalam hal sistem penjualannya, bawang merah akan ditimbang dulu oleh pedagang desa dan pedagang besar. Cara pembayaran secara tunai dalam transaksi pemasaran untuk pedagang desa sebesar 78,13\% dan pedagang besar 22\%. Alasan yang dikemukakan petani masih melakukan pemasaran bawang merah kepada pedagang desa adalah karena hubungan tetjadi karena adanya hubungan langganan (61,54\%), hubungan kekeluargaan (15,38\%) dan karena pertimbangan harga jual (23,08\%). Sedangan alasan petani melakukan pemasaran ke pedagang besar adalah karena faktor harga 
yang dinilai lebih tinggi (84,62\%), serta adanya hubungan langganan antara petani dengan pedagang tersebut (15,38\%). Dalam transaksi penjualan antara pihak petani dan penjual baik itu pedagang desa dan pedagang besar sebagian besar dilakukan di rumah petani (50\%) dan sebagian lagi di kebun (30\%), serta di pasar (20\%). Tinggi rendahnya persentase tempat transaksi pemasaran berkaitan dengan masalah tinggi rendahnya harga yang berlaku, dimana jika harga rendah biasanya transaksi banyak dilakukan di sawah sedangkan jika harga bawang merah sedang tinggi petani banyak melakukan transaksi dirumah.

Hasil penelitian Choirunisa et al, (2004) menunjukkan bahwa usahatani bawang merah di Brebes secara finansial dan ekonomi menguntungkan untuk diusahakan. Secara finansial memberikan keuntungan sebesar Rp 8.710.168 per hektar dan secara ekonomi memberikan keuntungan sebesar Rp 8.731.138 per hektar. Komoditi bawang merah Brebes mempunyai keunggulan komparatif yang ditunjukkan dengan nilai DRCR sebesar 0,51. Untuk analisis sensitivitas kenaikan harga sosial input (pupuk dan pestisida, tenaga kerja, sewa lahan dan nilai tukar) dan output secara parsial dan bersamaan dengan perubahan sampai 45\% masih memberikan keunggulan komparatif tetapi hal ini tidak berlaku untuk harga output yang turun hingga 45\%. Upaya yang dapat dilakukan pemerintah daerah adalah dengan melindungi eksistensi petani bawang merah agar tetap mampu berproduksi dan tetap mempunyai keunggulan komparatif.

Hasil penelitian Agustian et al., (2005) melaporkan bahwa harga sayuran di tingkat petani menunjukkan kecenderungan yang berfluktuasi. Harga komoditas bawang merah pada periode 1999-2004 masih meningkat tipis sebesar 0,15 persen/tahun. Harga bawang merah pada tahun 2004 di pasar konsumsi sebesar Rp 3.342/kg, sedangkan pad a tahun 1999 sebesar Rp 3.772/ kg. Pada periode 2000-2004, harga komoditas sayuran lainnya seperti cabe merah dan kubis secara rataan menurun. Harga cabe merah di sentra produsen Garut pada tahun 2000 mencapai Rp 4.627/kg dan pada tahun 2003 menjadi Rp 3.011/kg serta meningkat lagi menjadi Rp 4.944/kg di tahun 2004. Untuk komoditas kubis, di Jawa Barat rataan harga kubis pada tahun 2000 sebesar Rp 995,17 / kg dan menurun drastis menjadi Rp 676/kg di tahun 2004. Hal yang sarna juga terjadi di Sumatera Utara, harga rataannya mencapai Rp 777/kg tahun 2000 kemudian menurun menjadi Rp 581/kg tahun 2004.

\section{METODE KEGIATAN}

\section{Kerangka Pemecahan Masalah}

Kegiatan IbM ini dirancang sedemikian rupa untuk membantu pengusahatani bawang merah mengatasi berbagai masalah yang terkait dengan efisiensi modal kerja dan profitabilitas usaha.

\section{Pemilihan Khalayak Sasaran}

Pengambilan responden (khalayak sasaran) dalam kegiatan ini menggunakan tehnik purposive sampling, yaitu pengambilan sampel non-probabilitas yang disesuaikan dengan tujuan kegiatan. Populasi kegiatan ini adalah seluruh petani bawang merah di Kabupaten Brebes. Sedangkan khalayak sasaran yang diambil dalam penelitian ini adalah 30 petani bawang merah di desa Siwuluh, yang tergabung dalam kelompok usahatani bawang merah. Keterpilihan desa Siwuluh sebagai daerah kegiatan IbM didasarkan atas peringkat desa yang memproduksi bawang merah terbesar di Kabupaten Brebes yang merupakan sentra produksi bawang merah di Indonesia.

\section{Bahan dan Alat-alat Spesifik}

Bahan dan alat-alat spesifik yang digunakan dalam kegiatan ini adalah bahanbahan yang terkait langsung dengan pelatihan 
dan jasa konsultasi mengelola modal kerja pada usahatani bawang merah, yaitu bahan yang berupa modul (makalah) dan atau petunjuk praktis yang terdiri dari: (1) Memahami manajemen modal kerja; (2) Profitabilitas dan efisiensi usaha; (3) Manajemen kas dan persediaan; (4) Pendanaan aktiva lancar; (5) Menyusun laporan keuangan dan penganggaran pada Usahatani.

\section{Desain Alat, Kinerja dan Produktifitas- nya}

Modul pelatihan didesain sedemikian rupa sehingga memungkinkan pengusahatani bawang merah dapat mengaplikasikan petunjuk-petunjuk praktis tentang mengefisiensi biaya produksi, mengelola modal kerja dan mengetahui secara nyata laba-rugi usahatani. Untuk melakukan evaluasi terhadap hasil akhir kegiatan pengabdian ini mengunakan teknik wawancara (interview in depth) terhadap 30 pengusahatani (petani) yang mengikuti pelatihan ini, wawancara dilakukan dua (2) pekan setelah pelatihan dianggap selesai. Wawancara dilakukan untuk mengungkap atau mengetahui indikator: (i) peningkatan keuntungan usahatani bawang merah setelah mengikuti pelatihan; (2) penurunan biaya produksi bawang merah; (3) ada tidaknya perencanaan keuangan yang dibuat oleh petani dan (4) Peningkatan modal kerja usahatani.

\section{Pengumpulan dan Analisis Data}

Pengumpulan data dan Observasi di lakukan dengan metode wawancara untuk mengetahui beberapa hal yang terkait langsung dengan tujuan kegiatan ini yaitu: (1) jumlah produksi bawang merah ha ${ }^{-1}$ dalam satu tahun, (2) harga jual di tingkat petani, (3) jumlah nilai (Rp) penerimaan produksi bawang merah ha-1 dalam satu tahun, (4) nilai pengeluaran atau biaya produksi bawang merah ha ${ }^{-1}$ dalam satu tahun, yang terdiri dari: (i) bibit, (ii) pupuk buatan dan pupuk lainnya, (iii) pestisida dan pestisida lain-nya, (iv) tenaga kerja dalam dan luar keluarga dan (v) biaya lain-lain. (4) keuntungan yang diperoleh petani dan (5) margin pemasaran bawang merah pada petani untuk berbagai tujuan pemasaran.

Setelah data-data tersebut diperoleh atau dikumpulkan, langkah selanjutnya dilakukan pengelohan data untuk mengetahui jumlah penerimaan, pengeluaran, dan keuntungan usahatani. Langkah berikutnya adalah menganalisis hasil pengelohan data dengan metode analisis profitabilitas untuk mengetahui tingkat keuntungan riil yang diperoleh usahatani bawang merah ha ${ }^{-1}$ dalam satu tahun (dua kali musim tanam) serta diharapkan hasil analisis ini dapat mengetahui secara mendalam struktur pendapatan (kinerja profitabilitas)

\section{HASIL DAN PEMBAHASAN}

\section{Hasil Kegiatan}

Kegiatan IbM ini bermula dari observasi terhadap petani bawang merah yang bertempat tinggal menetap di desa Siwuluh yang berada dalam wilayah kecamatan Bulakamba Kabupaten Brebes. Berdasarkan hasil observasi dikembangkan menjadi penelitian tentang efisiensi dan profitabilitas usahatani bawang merah. Hasil penelitian (Rosyadi, 2009) menunjukan bahwa tingkat keuntungan usaha yang diperoleh petani bawang tidak signifikan, artinya keuntungan usahatani yang diperoleh tidak menambah kesejahteraan petani. Tingkat keuntungan (profitabilitas) dapat ditemukan dengan metode sederhana, sebagaimana juga dipraktekan kepada kelompok usahatani dalam kegiatan (pelatihan) ini yaitu:

Tabel 1. menunjukan hasil simulasi menghitung profitabilitas usahatani bawang merah dilokasi kegiatan. Produksi bawah 
merah ha ${ }^{-1}$ dalam dua kali tanam dalam setahun cukup besar yaitu 11,13564 ton (11.135,64 kg) dengan nilai penerimaan (revenue) produksi sebesar Rp.69.976.500. Sedangkan keuntungan bersih setelah dikurangi berbagai pengeluaran (biaya produksi) sebesar Rp.4.670.114, dengan R/ $\mathrm{C}$ rasio sebesar 1,1.

Tabel.1

Materi Praktek (Simulasi): Menghitung Tingkat Profitabilitas Usahatani Bawang Merahdi Kabupaten Brebes, 2008

\begin{tabular}{|c|c|c|c|}
\hline & Uraian & Nilai (Rp.) & \\
\hline A. & $\begin{array}{l}\text { Penerimaan } \\
\text { (1) Produksi (kg) } \\
\text { (2) Nilai (Rp) }\end{array}$ & $\begin{array}{l}11.135,64 \\
69.976 .500\end{array}$ & \\
\hline B & $\begin{array}{l}\text { Pengeluaran } \\
\text { (1) Bibit } \\
\text { (2) Pupuk buatan } \\
\text { (3) Pupuk lain-nya } \\
\text { (4) Pestisida } \\
\text { (5) Obat lain-nya } \\
\text { (6) Tenaga kerja } \\
\text { (i) Dalam keluarga } \\
\text { (ii) Luar Keluarga } \\
\text { (7) Biaya lain-nya } \\
\text { Total Pengeluaran }\end{array}$ & $\begin{array}{l}14.894 .776 \\
4.165 .750 \\
2.420 .550 \\
4.650 .224 \\
1.894 .450 \\
\\
5.865 .400 \\
28.266 .136 \\
3.149 .100 \\
65.306 .386\end{array}$ & $\begin{array}{l}\text { imulasi perhitung- } \\
\text { ahwa berusahatani } \\
\text { t memberikan ke- } \\
\text { un keutungan yang } \\
\text { t kecil jika diban- }\end{array}$ \\
\hline $\mathrm{C}$ & Keuntungan & 4.670 .114 & \\
\hline $\mathrm{D}$ & $\mathrm{R} / \mathrm{C}$ & 1,1 & depth) peneliti di \\
\hline
\end{tabular}
lapangan terhadap petani yang menyatakan bahwa tingkat keuntungan yang diperoleh belum cukup untuk dapat memenuhi kebu- tuhan ekonomi rumah tangga petani. Atau dengan dengan kalimat lain, usahatani bawang merah dilokasi penelitian tidak memberikan keuntungan yang siginfikan (unprofitable) terhadap ekonomi rumah tangga petani. Keuntungan yang kecil itu disebabkan oleh tingkat biaya produksi yang telalu tinggi, yaitu mencapai 90 persen dari total revenue. Biaya produksi tertinggi dikeluarkan untuk upah tenaga kerja yang mencapai 52,26 persen, kemudian diikuti secara ber-urutan yaitu bibit 22,81 persen, pupuk 10,01 persen, pestisida 10,00 persen dan biaya lain-nya 4,82 persen.

\section{Implikasi dan Temuan}

Kegiatan IbM ini berimplikasi pada kebijakan pemangku kepentingan di tingkat Kabupaten untuk memainkan peran strategis sebagai upaya meningkatkan daya saing produk bawang merah sekaligus meningkatkan pendapatan petani di daerah sentra produksi, diperlukan beberapa hal penting yang harus dilakukan sebagai berikut: (1) Pemerintah Kabupaten dan instansi (dinas) terkait disarankan untuk melakukan kebijakan-kebijakan yang mengarah pada penguatan kelembagaan kemitraan usaha komoditas bawang merah dengan visi "Mencapai Indonesia Sebagai Eksportir Bawang Merah”; (2) Pemerintah Kabupaten dapat mewujudkan: (i) tersedianya varietas baru yang produktif, adaptif dan tahan terhadap hama/penyakit, (ii) tersedianya teknologi produksi dan pengelolaan benih bermutu, konsep jaminan dan standarisasi mutu sebagai langkah awal untuk membangun industri benih nasional yang tangguh dan mandiri; (iii) Tersedianya teknologi budidaya yang ramah lingkungan dan efisien dengan memanfaatkan sumberdaya lokal secara optimal dan berkelanjutan untuk menghasilkan produk hortikultura modern dan efisien sekaligus membuka peluang munculnya industri sarana penunjang di 
berbagai daerah; (iv) Tersedianya teknologi pengendalian hama/penyakit yang berbasis pada penggunaan musuh alami dan pengurangan pestisida sintetis serendah mungkin; (v) Tersedianya teknologi pasca panen untuk efisiensi pengemasan, konservasi mutu segar, diversifikasi produk yang berkaitan dengan peningkatan nilai tambah industri hortikultura. (3) Pengusahatani, melakukan langkah-langkah efisiensi terhadap penggunaan pestisida, pupuk, dan tenaga kerja serta melakukan langkah-langkah untuk meningkatkan produksi bawang merah dengan cara penggunaan bibit unggul dan dan tahan tehadap hama, serta penggunaan teknologi produksi dan pengelolaan benih yang bermutu tinggi.

\section{Temuan Baru Di Lapangan}

Selama kurang lebih 6 (bulan) berinteraksi dan terlibat langsung dengan kelompok usahatani bawang merah dalam kegiatan IbM ini, ditemukan beberapa permasalahan baru petani bawang merah yang cukup mendesak untuk di carikan solusi-nya, yaitu: (1) Disparitas yang sangat besar antara harga jual di tingkat petani dan harga di supermarket; (2) Harga turun drastis pada saat panen raya bawang merah; (3) Kualitas bawang merah yang rendah (mudah mengalami pembusukan); (4) Rantai pemasaran yang sangat panjang; dan (5) Petani belum mampu memasok kebutuhan bawang merah antar-pulau dan antar-negara.

\section{SIMPULAN}

Program IbM ini dilaksanakan kurang lebih selama 6 bulan oleh tim kegiatan yang beranggotakan 1 orang ketua dan 2 orang anggota yang berasal dari FE Universitas Muhammadiyah Surakarta. Kegiatan $\mathrm{I}_{\mathrm{b}} \mathrm{M}$ ini telah menghasilkan luaran berupa jasa dan metode praktis penerapan manajemen modal kerja spesifik pada usahatani bawang merah.
Kegiatan pokok program ini menyelenggarakan pelatihan "Penerapan Manajemen Modal Kerja Praktis Pada Usahatani Bawang Merah” di Desa Siwuluh Bulakamba Brebes. Pelatihan didesain sedemikian rupa, sehingga memungkinkan peserta (seluruh anggota kelompok usahatani) dapat memahami sekaligus mempraktek-an bagaimana mengelola modal kerja secara praktis dan sederhana. Berdasarkan wawancara mendalam, diketahui bahwa kegiatan IbM ini sangat membantu petani bawang merah dalam menjalankan usaha-nya, terutama ketika petani akan mengajukan KUR dimana salah satu persyaratan-nya menyusun anggaran modal. Pengelolaan modal secara praktis juga membantu petani bawang merah dalam memprediksikan keuntungan yang akan diperoleh serta memudahkan petani untuk menurunkan biaya produksi tanpa harus mengurangi kualitas bawang merah.

Untuk penguatan kontribusi bagi usahatani bawang merah yang dijalankan petani, serta mengawal petani benar-benar mempraktekan pengelolaan modal kerja, tim kegiatan IbM juga melaksanakan kegiatan pendampingan dan jasa konsultasi. Sehingga secara umum kegiatan ini dianggap berhasil berdasarkan interview in depth yang mengungkapkan tentang beberapa hal yaitu: (i) mengelola modal kerja secara tepat, efisien dan efektif; (ii) melalukan efisiensi terhadap input (biaya produksi); (iii) mengalokasikan kas dan persediaan dalam rangka mempertahankan keberlangsungan usahatani bawang merah; (iv) memahami perencanaan keuangan dan dapat melakukan penganggaran modal dan keuntungan secara tepat dan (v) meningkatkan modal kerja usahatani bawang merah.

\section{PERSANTUNAN}

Ucapan terima kasih kami sampaikan Dr. Suryo Hapsoro Tri Utomo, selaku 
Direktur P2M-Dirjen Dikti yang telah memberikan kesempatan dan menyetujui pelaksanaan penelitian ini dengan sumber pembiayaan dari DIPA DP2M-Dirjen Dikti. Kepada Dr. Harun Joko Prayitno, selaku Ketua LPPM-UMS yang telah memberikan kesempatan kepada tim kegiatan ini untuk mengikuti kompetisi program IbM;. Tidak lupa juga kami sampikan terima kasih kepada rekan-rekan pengkaji pendukung (peserta seminar sinopsis), Dra. Mabruroh, M.M.; Drs. Yuli Tri Cahyono, M,M.; Drs. Suyatmin, M.Si.; Dra. Chuzaimah, M.M; Drs. Edi
Priyono, M.M.; Drs Ma'ruf, M.M, dan Sri Murwanti, SE, M.M. Ir. Maulidyah Indira, M.Si. yang telah memberikan kritik, usul perbaikan konstruktif untuk penyempurnaan laporan kegiatan IbM ini. Terima kasih kami sampikan kepada Mas Nafi' yang telah membantu tim kegiatan dalam pengurusan kelengkapan administrasi usul penelitian maupun laporan kegiatan ini. Kami sampaikan terima kasih juga kepada berbagai pihak yang telah membantu kelancaran proses penyelesaian kegiatan hingga menjadi laporan akhir.

\section{DAFTAR PUSTAKA}

Adiyoga, W. 2000. "Perkembangan Ekspor-Impor dan Ketidakstabilan Penerimaan Ekspor Komoditas Sayuran di Indonesia”. Jurnal Hortikultura. Vol 10 (l): 70-81.

Agustian, A., Zulham, A., Syahyuti, Tarigan, H., Supriatna, A., Supriyatna, Y., Nurasa, T. 2005. "Analisis Berbagai Bentuk Kelembagaan Pemasaran dan Dampaknya terhadap Peningkatan Usaha Komoditas Pertanian”. Laporan Akhir Penelitian. PSEKP-Badan Penelitian dan Pengembangan Pertanian. Jakarta: Departemen Pertanian

Andersen, P., \& Petersen, N. C. 1993. "A Procedure for Ranking Efficient Units in Data Envelopment Analysis”. Management Science, 39(10), 1261-1264.

Banker, R. D., Chames, A, \& Cooper, W. W. 1984. "Some Models for Estimating Tech-nical and Scale Inefficiencies in Data Envel-opment Analysis”. Management Science, 30(9), 1078-1092.

Budiarto, Joko. Dukungan Teknologi Bagi Pengembangan Hortikultura Tahun 2003. Jakarta: Badan Penelitian dan Pengembangan Pertanian.

Bappeda Brebes. 2005. "Produk Unggulan Pertanian Di Kabupaten Brebes". www.brebeskab.go.id .

BPS Brebes. 2008. Kabupaten Brebes Dalam Angka Tahun 2008. Brebes: Badan Pusat Statistik Kabupaten Brebes.

Bhat, R., Bharat, B., dan Elan Reuben. 1998. Methodology Note: Data Envelopment Analysis (DEA). India: IIM Ahmedabad.

Bowlin, WF. 1996. "Measuring Performance: An Introduction to Data Envelopment Analysis (DEA)”. Journal of Cost Analysis, 3-7.

Cooper, W.W., Seiford, L.M. and Kaoru Tone. 2002. Data Envelopment Analysis: a Comprehensive Text with Models, Applications. References and DEA-Solver Software, $3^{\text {rd }}$ ed., Boston: Kluwer Academic 
Daft, L.D. 2007. Manajemen. Jilid 1, Edisi 6: Terjemahan, Jakarta: Salemba Empat.

Griffin R.W. 2004. Manajemen. Jilid 1, Edisi 7: Terjemahan, Jakarta: Erlangga.

Gonarsyah, Isang. 1992. "Peranan pasar Induk Kramat Jati sebagai barometer harga sayur mayur di wilayah DKI Jakarta”. Mimbar Sosek, Bogor: Institut Pertanian Bogor. (5):4348.

Hadi, P.U., H. Mayrowani, Supriyati dan Sumedi. 2000. Review and Outlook Pengembangan Komoditas Hortikultura. Seminar Nasional Perspektif Pembangunan Pertanian dan Kehutanan Tahun 2001 ke Depan. Bogor Pusat Penelitian Sosial Ekonomi Pertanian. Badan Penelitian dan Pengembangan Pertanian.

Irawan, B., Simatupang P, Sugiarto, Supadi, Agustin, NK., Sinuraya, JF. 2006. "Panel Petani Nasional (PATANAS): Analisis Indikator Pembangunan Pertanian dan Pedesaan”. Laporan Akhir Penelitian. PSEKP-Badan Penelitian dan Pengembangan Pertanian, Jakarta: Departemen Pertanian.

Kuma’at, R. 1992. “Sistem pemasaran sayuran dataran tinggi di provinsi Sulawesi Utara”. Thesis MS - FPS IPB, Bogor.

Mubyarto. 1989. Pengantar Ekonomi Pertanian. Jakarta: LP3ES.

Rachman, H.P.S. 1997. “Aspek permintaan, penawaran dan tataniaga hortikultura di Indonesia”. Forum Agro Ekonomi 15 (1 dan 2) : 44-56. Laporan Akhir Pusat Penelitian dan Pengembangan Sosial Ekonomi Pertanian. Badan Penelitian dan Pengembangan Pertanian, Bogor.

Nopirin. 1997. Pengantar IImu Ekonomi Makro dan Mikro. Yogyakarta: BPFE-UGM.

Nurasa, T., dan Darwis, V. 2007. Analisis Usahatani dan Keragaan Marjin Pemasaran Bawang Merah di Kabupaten Brebes”. Jurnal Akta Agrosia, Vol. 10 No.1 h. 40-48.

Saptana, Indraningsih, K.C. dan Hastuti, E.L. 2006. Analisis Kelembagaan Kemitraan Usaha di Sentra-Sentra Produksi Sayuran. Bogor: Pusat Analisis Sosial Ekonomi dan Kebijakan Pertanian.

SudaryantoT., Y. Yusdja, A. Purwoto, K.M. Noekman, A.Bwariyadi, dan W.H. Limbang. 1993. “Agribisnis Komoditas Hortikultura”. Laporan Akhir Pusat Penelitian dan Pengembangan Sosial.

Talluri, S. 2000. “Data Envelopment Analysis: Models and Extensions”. International Journal of Flexible Manufacturing System.

Thamrin, M., Ramlan, Armiati, Ruchjaningsih dan Wahdania. 2003. "Pengkajian Sistem Usahatani Bawang Merah Di Sulawesi Selatan”. Jurnal Pengkajian dan Pemgembangan Teknologi Pertanian Vol. 6, No. 2: 141-153 